\title{
Spawning behavior of Palola viridis (Polychaeta: Eunicidae) in American Samoa
}

Received: 29 August 2008/ Accepted: 26 January 2009/Published online: 14 February 2009

(C) Springer-Verlag 2009
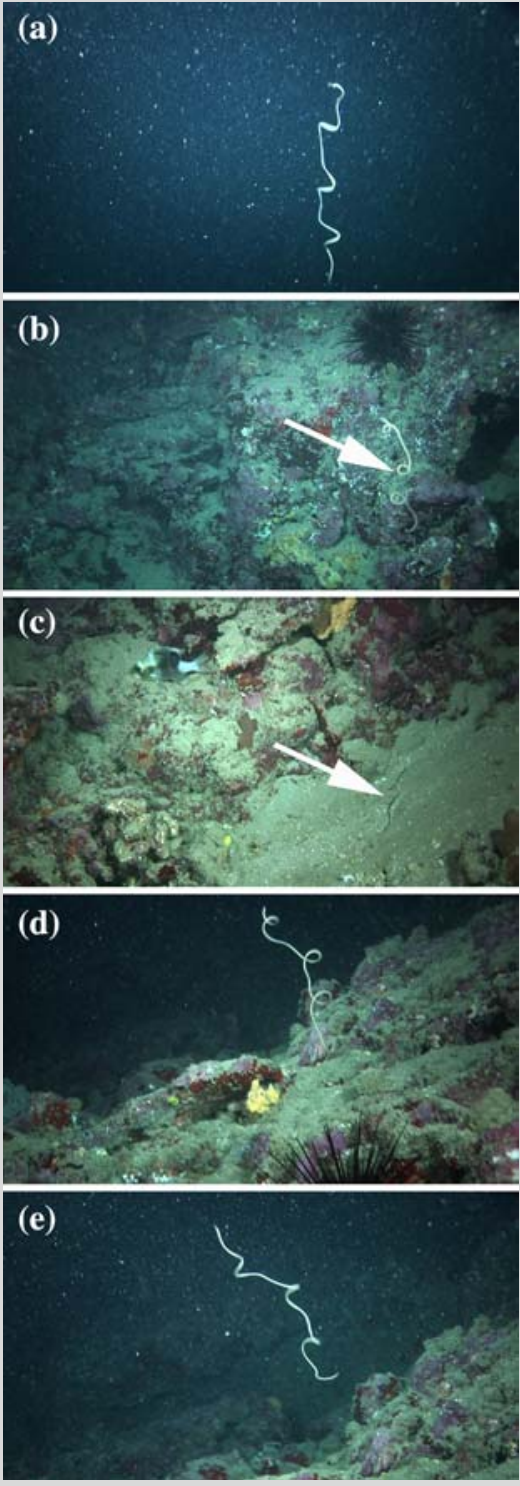

Fig. 1 Video captures of Palola viridis spawning behavior. a After initial ascent of 1-3 $\mathrm{m}, \mathbf{b}$ epitoke begins descent (note urchin in background), $\mathbf{c}$ contacts substrate, $\mathbf{d}, \mathbf{e}$ begins toward surface (notice urchin in foreground)

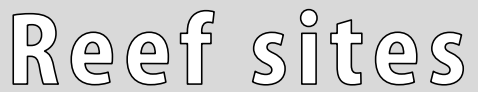

The relationship of synchronous spawning and the phases of the moon has been clearly demonstrated and documented for numerous marine organisms. The people of Samoa have known about this phenomenon for centuries and can accurately predict the October/November spawning of the palolo worm (Palola viridis). The spawned epitokes of this invertebrate are harvested as a local delicacy. Previous studies into this synchronous spawning event (Gray 1847; Caspers 1984) have been restricted to above water observations. In November 2007 and again in October 2008 on the island of Tutuila, American Samoa $\left(14^{\circ} 30^{\prime} \mathrm{S}, 170^{\circ} 30^{\prime} \mathrm{W}\right)$ SCUBA was used to observe the release of palolo worm epitokes. While observing the event at a depth of $13 \mathrm{~m}$, an unusual behavior by the newly released epitokes was consistently observed. When the epitokes are released, they begin swimming toward the surface for approximately 1-3 m using a clockwise spiraling motion. After this initial rise in the water column, the epitokes then alter the direction and begin swimming back down toward the reef. Upon coming in contact with the reef, the epitokes then resume their original direction back toward the water surface, giving the entire release pattern an 'N'-shaped profile (Fig. 1).

It has been well documented by Schulze (2006) that epitokes, which have eyespots on each body segment, react to light. Phototactic and geotactic responses were ruled out by observing the behaviors using longwave red lighting by placing resin filters (equivalent to Kodak wratten \#25) over the light source, as well as placing the light source directly above the reef or to the side. Neither lighting direction nor light spectrum had an effect on the witnessed behaviors. The reason for this pattern is unknown, but may be a method to ensure that the epitoke is swimming in the correct direction towards the surface.

\section{References}

Caspers H (1984) Spawning periodicity and habitat of the palolo worm Eunice viridis (Polychaeta: Eunicidae) in the Samoan Islands. Mar Biol 79(3):229-236

Gray JE (1847) An account of Palolo, a sea worm eaten in the Navigator Islands. Proc Zool Soc London 15:17-18

Schulze A (2006) Phylogeny and genetic diversity of palolo worms (Palola, Eunicidae) from the tropical North Pacific and the Caribbean. Biol Bull 210:25-37

D. P. Brown $(\bowtie)$

National Park of American Samoa, Pago Pago, AS 96799, USA

e-mail: Paul_Brown@nps.gov 